\title{
REVISED Application of ARID1A to murine formalin-fixed paraffin embedded tissue using immunohistochemistry [version 3;
}

\section{peer review: 2 approved]}

\section{Will Howat, Jodi Miller, Ioannis Gounaris}

Cancer Research UK Cambridge Institute, University of Cambridge, Li Ka Shing Centre, Cambridge, CB2 ORE, UK

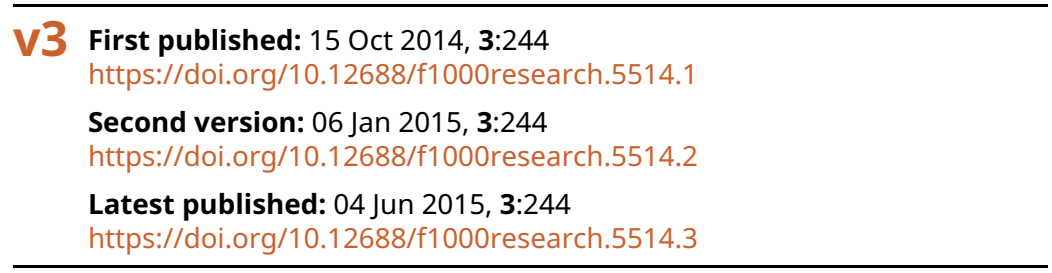

\section{Abstract}

ARID1A is a known suppressor of tumour formation and the Human Protein Atlas antibody HPA005456 has been demonstrated in previous literature to stain tumour tissue by immunohistochemistry (IHC) in formalin-fixed paraffin embedded human tissue and human cell lines. This article details the validation of this antibody for immunohistochemistry of formalin-fixed paraffin embedded murine tissue using a Leica BondMax immunostainer. Using Western blot and IHC on murine wild-type and knockout tissue we have demonstrated that this antibody to ARID1A correctly stains murine tissue by immunohistochemistry.

\section{Keywords}

immunohistochemistry, antibody , ARID1A, tissue

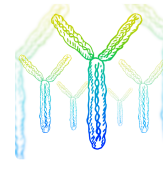

This article is included in the Antibody

Validations gateway.

\section{Open Peer Review}

Approval Status

1

2

version 3

(revision)

04 Jun 2015

version 2

(revision)

06 Jan 2015

version 1

15 Oct 2014

$\begin{array}{cc} & \\ \text { view } & \text { view } \\ ? & ? \\ \text { view } & \text { view }\end{array}$

1. Andrew D. Chalmers, University of Bath, Bath, UK

\section{Stephen McQuaid, Queen's University}

Belfast, Belfast, UK

Any reports and responses or comments on the article can be found at the end of the article. 
Corresponding author: Will Howat (will.howat@cruk.cam.ac.uk)

Competing interests: No competing interests were disclosed.

Grant information: WH and JM are funded by Cancer Research UK, IG is funded by an MRC Clinical Research Training Fellowship, grant number G1001957.

The funders had no role in study design, data collection and analysis, decision to publish, or preparation of the manuscript.

Copyright: $\odot 2015$ Howat $W$ et al. This is an open access article distributed under the terms of the Creative Commons Attribution License , which permits unrestricted use, distribution, and reproduction in any medium, provided the original work is properly cited. Data associated with the article are available under the terms of the Creative Commons Zero "No rights reserved" data waiver (CC0 1.0 Public domain dedication).

How to cite this article: Howat W, Miller J and Gounaris I. Application of ARID1A to murine formalin-fixed paraffin embedded tissue using immunohistochemistry [version 3; peer review: 2 approved] F1000Research 2015, 3:244

https://doi.org/10.12688/f1000research.5514.3

First published: 15 Oct 2014, 3:244 https://doi.org/10.12688/f1000research.5514.1 


\section{REVISED Amendments from Version 2}

The article type has been changed from 'Research Note' to 'Antibody Validation Article' to better reflect the type of study presented.

See referee reports
This demonstrates a nuclear expression in all cell lines and in the majority of tissue types ${ }^{6}$. However, the Western blot data were not supportive and did not produce staining corresponding to the expected size, although the data from a protein array did confirm a peak at the expected size. The antibody has been used to stain human colorectal cancers ${ }^{7}$, clear cell carcinomas ${ }^{8}$ and on a variety of clear cell cancer cell lines ${ }^{9}$ by immunohistochemistry.

To our knowledge, whilst the sequence homology between mouse and human ARID1A is $95 \%$, this antibody has not been qualified using knockout tissue and has not been tested or published on murine tissue and this work represents the first data to do so.

\section{Materials and methods}

Reagent details

Details of all reagents with reference to the immunohistochemical staining procedure can be found in Table 1 .

\section{Antibody details}

Anti-ARID1A is a monospecific rabbit polyclonal generated to a PrEST sequence - PGLGNVAMGPRQHYPYGGPYDRVRTEPG IGPEGNMSTGAPQPNLMPSNPDSGMYSPSRYPPQQQQQQ QQRHDSYGNQFSTQGTPSGSPFPSQQTTMYQQQQQNYK (Table 2). The homology of the PrEST sequence used as immunogen

Table 1. Details of ancillary reagents for immunohistochemistry.

\begin{tabular}{|c|c|c|c|c|}
\hline Process & Reagent & Manufacturer & Catalogue Number & Concentration \\
\hline Fixation & Neutral Buffered Formaldehyde & Sigma & HT501128 & $10 \%$ \\
\hline \multirow{3}{*}{ Pretreatment } & ER1 (Sodium Citrate, pH6) & Leica Biosystems & AR9961 & Proprietary \\
\hline & ER2 (Tris/EDTA, pH9) & Leica Biosystems & AR9640 & Proprietary \\
\hline & Enzyme 1 (Proteinase K) & Leica Biosystems & AR9551 & $100 \mu \mathrm{g} / \mathrm{ml}$ \\
\hline \multirow{5}{*}{ Staining } & Peroxide Block & Leica Biosystems & DS9263 & Proprietary \\
\hline & Streptavidin - HRP & Leica Biosystems & DS9263 & Proprietary \\
\hline & Diaminobenizidine (DAB) & Leica Biosystems & DS9263 & Proprietary \\
\hline & Haematoxylin & Leica Biosystems & DS9263 & Proprietary \\
\hline & DAB Enhancer & Leica Biosystems & AR9452 & Proprietary \\
\hline \multirow{3}{*}{ Washes/Blocks } & Bond Wash (Tris Buffer) & Leica Biosystems & AR9590 & Proprietary \\
\hline & Antibody Diluent & Leica Biosystems & AR9352 & Proprietary \\
\hline & Avidin/Biotin Block & Vector Laboratories & SP-2001 & Proprietary \\
\hline
\end{tabular}

Table 2. Details of primary and secondary antibodies.

\begin{tabular}{|l|l|l|l|}
\hline Antibody & Manufacturer & Catalogue Number & RRID \\
\hline ARID1A & Atlas Antibodies & HPA005456 & AB_1078205 \\
\hline GAPDH (Clone 14C10) & Cell Signaling & 2118 & AB_561053 \\
\hline Donkey anti-Rabbit Biotin & Jackson Immunoresearch & $711-065-152$ & AB_2333077 \\
\hline Goat anti-Rabbit IRDye 680LT & Li-Cor Biosciences & $926-68021$ & AB_10706309 \\
\hline Goat anti-Rabbit IRDye 800CW & Li-Cor Biosciences & $926-32213$ & AB_621848 \\
\hline
\end{tabular}


is $95 \%$, when verified with BLAST against the mouse sequence. The lot number used for all validations was A40072 and for subsequent staining was D81856. A concentration of $1 \mu \mathrm{g} / \mathrm{ml}$ was used for initial validations and $0.5 \mu \mathrm{g} / \mathrm{ml}$ for final runs.

Donkey anti-rabbit biotin (Jackson Immunoresearch, Table 2) is specific for Rabbit IgG (Heavy and Light chains) and was affinity purified to remove cross-reactions to Bovine, Chicken, Goat, Guinea Pig, Syrian Hamster, Horse, Human, Mouse, Rat and Sheep. All slides were stained with a concentration of $4.8 \mu \mathrm{g} / \mathrm{ml}$.

Anti-GAPDH was used as a loading control for Western blots and was a rabbit monoclonal (Cell Signaling, Table 2). Detection antibody for the Western blot for ARID1a was Goat anti-rabbit IR Dye 680LT (Li-Cor Biosciences, Table 2) used at a concentration of $0.1 \mu \mathrm{g} / \mathrm{ml}$ and detection of GAPDH was Goat anti-rabbit IR Dye 800CW (Li-Cor Biosciences, Table 2).

Tissue details

All tissues and cell pellets used during the validation were fixed in Neutral Buffered Formaldehyde as specified (Table 3) before being transferred directly to $70 \%$ ethanol for no longer than 3 days. Tissue processing was conducted on a Leica ASP300 through graded ethanols before clearing in xylene and impregnation in molten paraffin wax (Fisher). All tissue sections were cut on a Leica rotary microtome at $3 \mu \mathrm{m}$.

Arid $1 \mathrm{a}^{-/-}$mice were created by crossing Floxed Aridla mice with ROSA26 Cre-ERT2 mice and resultant genotyping. Loss of Arid1a expression is expected following intraperitoneal injection of Tamoxifen.

Floxed Aridla mice were a gift from Dr. Peri Tate, Sanger Institute, Hinxton UK; ROSA26 Cre-ERT2 mice were a gift from Prof Chambon, IGBMC, France. ES-2 cells were purchased from ATCC and RMG-II were a gift from Prof Huntsman, British Columbia Cancer Agency, Vancouver, Canada.

\section{Experiment details}

Western blot. Protein was extracted from the two clear cell carcinoma cell lines using a Tris-EDTA lysis buffer and run on a nondenaturing 3-8\% Tris-acetate gel (Life Technologies). Following

Table 3. Details of tissue and cell pellet used during the validation.

\begin{tabular}{|l|l|l|l|l|}
\hline Species & Tissue Type & $\begin{array}{l}\text { Strain/Cell } \\
\text { line }\end{array}$ & Details & $\begin{array}{l}\text { Fixation } \\
\text { Time }\end{array}$ \\
\hline Murine & Uterus & C57Bl6 & Female & $16 \mathrm{hrs}$ \\
\hline Murine & Uterus & $\begin{array}{l}\text { C57Bl6 KO } \\
\text { Arid1at/fll }\end{array}$ & Female & $24 \mathrm{hrs}$ \\
\hline Human & Cell Pellet & ES-2 & & $20 \mathrm{hrs}$ \\
\hline Human & Cell Pellet & RMG-II & & $20 \mathrm{hrs}$ \\
\hline
\end{tabular}

electrophoresis, the transfer membrane was probed with $0.2 \mu \mathrm{g} / \mathrm{ml}$ of anti-rabbit ARID1A (HPA005456) at $4{ }^{\circ} \mathrm{C}$ overnight and $0.1 \mu \mathrm{g} / \mathrm{ml}$ anti-GAPDH (14C10) for the same length of time. Detection of the anti-rabbit ARID1A was with Goat anti-rabbit IRDye 680LT (Li-Cor Biosciences) and the GAPDH was with Goat anti-rabbit IRDye $800 \mathrm{CW}$ (Li-Cor Biosciences) both at $0.1 \mu \mathrm{g} / \mathrm{ml}$.

Immunohistochemistry. Slides were deparaffinised and rehydrated on a Leica ST5020 using Xylene (Sigma) for $2 \times 10$ mins and ethanol (Fisher), $2 \times 100 \%$ ethanol followed by $1 \times 70 \%$ ethanol for 5 mins each. Following staining, all slides were dehydrated, cleared and mounted and coverslipped in DPX (Fisher).

The antibody was validated on a Leica BondMax instrument using a Leica Intense R kit to a standardised in-house protocol. All reagents were from Leica as part of the Intense R kit and were conducted at room temperature, unless otherwise specified. All staining steps included individual washes in Leica Bond Wash after each step, as part of the protocol (Table 4). A full protocol for the validated conditions can be found in the supplementary material. In this protocol, the step named "primary" refers to the anti-ARID1a primary antibody.

A slide using the same conditions and retrieval but omitting the primary antibody was used to control for any background staining due to the retrieval and detection steps.

Imaging. All slides were digitised using a Leica Scanscope AT2 at $0.5 \mu \mathrm{m} /$ pixel resolution. Datasets can be viewed by downloading the Leica Imagescope free viewer at http://www.leicabiosystems.com/pathology-imaging/aperio-epathology/integrate/ imagescope/.

\section{Table 4. Staining protocol for ARID1A immunohistochemistry.}

\begin{tabular}{|c|c|c|}
\hline Protocol steps & Reagent & $\begin{array}{l}\text { Time } \\
\text { (mins) }\end{array}$ \\
\hline \multirow{3}{*}{ Antigen Retrieval } & ER1 & 20 \\
\hline & Or ER2 & 20 \\
\hline & Or Enz1 & 10 \\
\hline \multirow{8}{*}{ Staining } & Peroxide Block & 5 \\
\hline & Avidin & 10 \\
\hline & Biotin & 10 \\
\hline & ARID1A & 15 \\
\hline & $\begin{array}{l}\text { Donkey anti-rabbit } \\
\text { Biotin }\end{array}$ & 8 \\
\hline & SA-HRP & 8 \\
\hline & $\mathrm{DAB}$ & 5 \\
\hline & DAB Enhancer & 10 \\
\hline Counterstaining & Haematoxylin & 5 \\
\hline
\end{tabular}




\section{Results}

To determine the correct cell line to utilise and to confirm the equivocal Western blot data from Human Protein Atlas, the antibody was used to stain a Western blot of two cell lines; ES-2 and RMG-II, both of which are cell lines derived from clear cell carcinoma and have been previously demonstrated as ARID1a wild-type and mutated, respectively ${ }^{9}$. It could be demonstrated that the HPA ARID1A antibody showed positive expression in ES-2 cell lines at the expected size of $270 \mathrm{kDa}$ and no staining for RMG-II. The loading control of GAPDH showed that there were no loading issues (Figure 1). Thus, these cell lines were chosen to be grown, formalin fixed and processed into paraffin wax for immunohistochemical validation.

For immunohistochemical validation, ES-2 and RMG-II cell lines were stained using three antigen retrieval conditions; ER1 (Sodium Citrate, pH6), ER2 (Tris/EDTA, pH9) and Enzyme 1 (Proteinase K, $100 \mu \mathrm{g} / \mathrm{ml}$ ) at a fixed antibody concentration of $1 \mu \mathrm{g} / \mathrm{ml}$. The enzyme retrieval demonstrated no nuclear signal for either ES2 or RMG-II cell pellets and was discarded for future work (Figure 2; Dataset a). The ER2 condition did demonstrate significant nuclear staining in the ES2 cell pellet with minimal background staining in the RMG-II cell pellet (Figure 2; Dataset b).

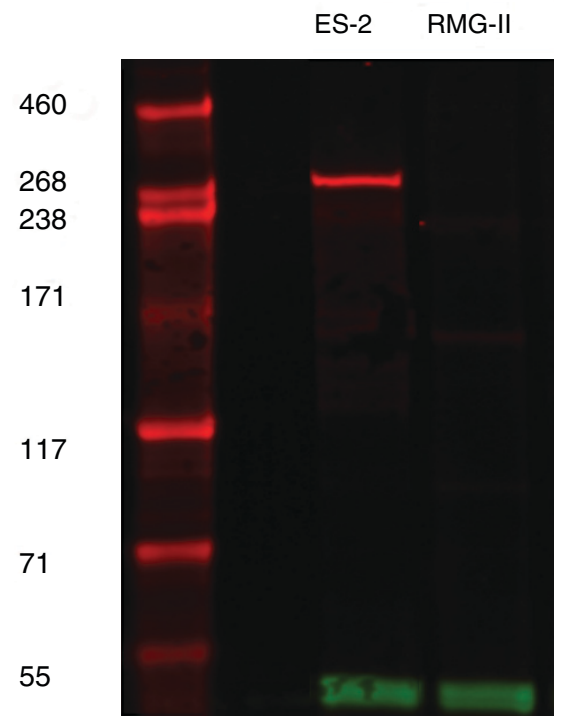

Figure 1. Western blot of ES2 and RMG-Il clear cell carcinoma cells lines. ARID1A (red band) can be seen to be present at approximately $270 \mathrm{kD}$ in ES2 cell line only. GAPDH at 37kD (green band) represents loading control.

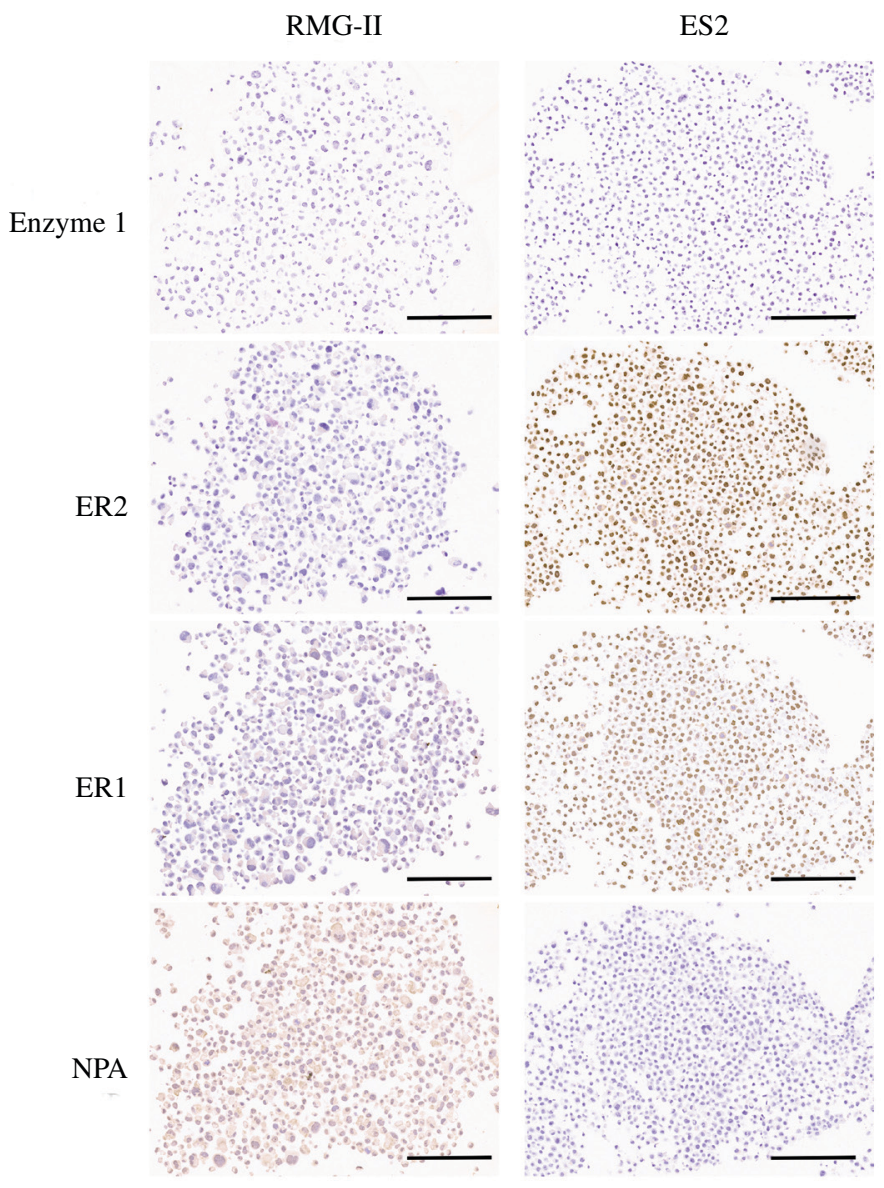

Figure 2. ES2 and RMG-II cell lines stained by immunohistochemistry with anti-ARID1A using three antigen retrieval conditions, ER1, ER2 and Enzyme 1. NPA denotes No Primary antibody control and represents the ER2 condition. Bar $=200 \mu \mathrm{m}$. 
However, the staining in the ER1 condition was determined to give the best signal:noise ratio with no background cytoplasmic staining and crisp nuclear staining for the cell pellet (Figure 2; Dataset c). Control slides, omitting the primary antibody, were negative except for the ER2 condition in the RMG-II cell pellet where a weak cytoplasmic background could be seen (Figure 2; Dataset d). Thus there was minimal background inherent in the staining procedure. It was therefore determined that the antibody showed specificity for formalin-fixed paraffin embedded tissues and could be run on murine tissue.

Murine uterine tissue was used as positive control tissue samples, given the literature data on cell lines and endometrial tissue. The ER 1 condition at $1 \mu \mathrm{g} / \mathrm{ml}$ demonstrated clean nuclear staining in the uterine epithelial compartment as well as nuclear staining of stromal cells. However, the nuclear staining in the stroma was not universal and distinct negative nuclei could be seen (Figure 3A; Dataset e). There was no cytoplasmic or extracellular stromal background staining present and the antibody titrated successfully losing the intensity of staining, as expected (Dataset e). Following this, a concentration of $0.5 \mu \mathrm{g} / \mathrm{ml}$ was used for future preparations which provided clear and consistent staining in repeated batches using a different antibody lot (Dataset f). A No Primary antibody control (NPA) showed no staining in the epithelial or nuclear compartment (Figure 3B; Dataset e).

Finally, when applied to a genetically engineered, tamoxifeninduced, Arid1a knockout mouse model, the staining in the uterine epithelium could be almost completely abrogated (Arrow, Figure 4b) when compared to the same area in a wild-type animal (Arrow, Figure 4a) with a small focal area of epithelial staining still present. There was no effect of the $\mathrm{KO}$ on the staining in the stromal compartment.

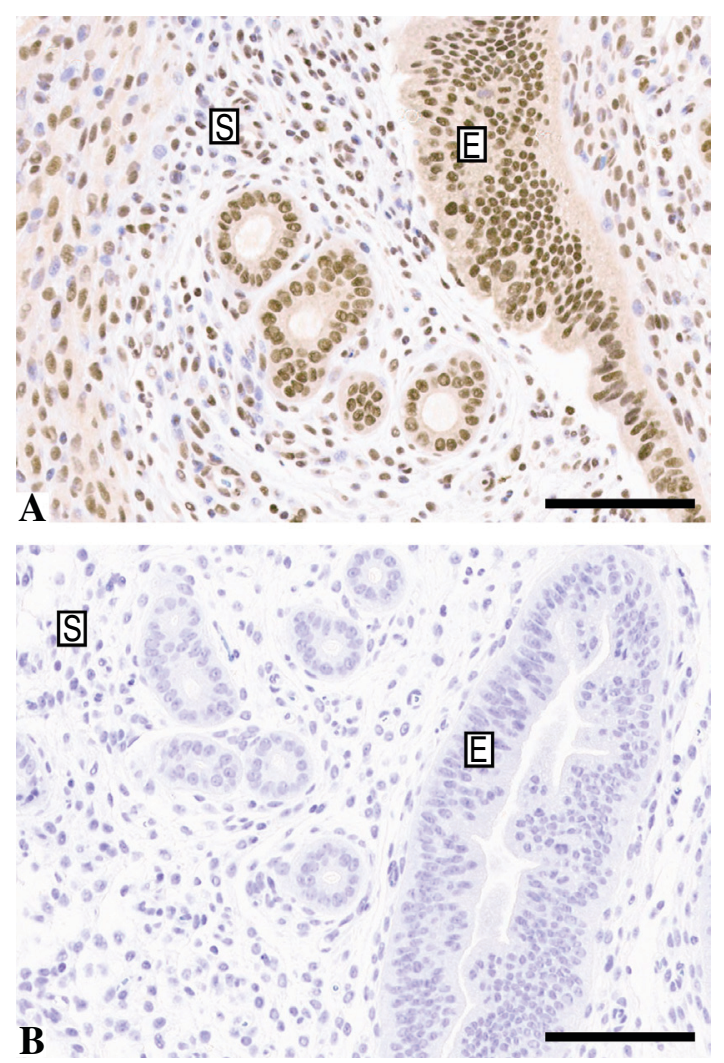

Figure 3. A) Murine uterine tissue stained by immunohistochemistry with anti-ARID1A using the ER1 condition and a concentration of $1 \mathrm{ug} / \mathrm{ml}$ demonstrating clear nuclear staining of the epithelial compartment (E) and negative nuclei in the stromal compartment (S). B) No primary antibody control of a similar area of epithelium/ stroma. Bar $=100 \mu \mathrm{m}$.

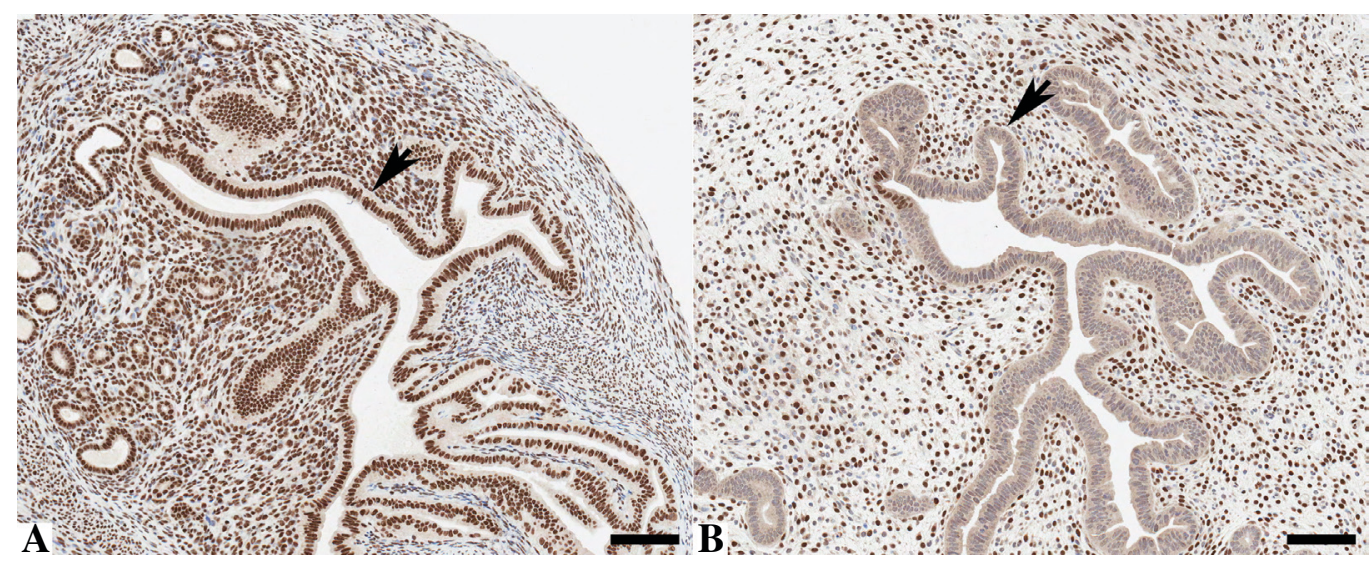

Figure 4. Murine uterine tissue stained by immunohistochemistry with anti-ARID1A demonstrating nuclear staining in wild-type mice (A) but loss of epithelial staining after ARID1A knock-out in Arid1 $a^{t / f / t}$ mice $(\mathbf{B})$. Bar $=100 \mu \mathrm{m}$. 
Dataset 1. Whole slide images from antibody validation of HPA005456 for immunohistochemistry - Version 2

http://dx.doi.org/10.5256/f1000research.5514.d41579

Detailed legends for each dataset (Datasets a-f) can be found in the text file provided. For Version 2 an additional image was added to Dataset e.

\section{Conclusions}

It is clear from the use of ES2 and RMG-II cell lines that the Atlas Antibodies ARID1A antibody is specific for ARID1A in both Western blots and formalin-fixed paraffin embedded preparations of human origin and, coupled with the literature evidence, that it is validated in human tissue.

The staining pattern when applied to murine uterus showing a clear nuclear pattern, where there is a high level of sequence homology between the two species, is again consistent with the literature on this protein. When stained on an ARID1a knockout mouse model, the staining could be almost completely abrogated in the epithelial compartment but not in the stroma. Knockout mice generated in this manner are almost never $100 \%$ complete as in some cells recombination will not be induced due to issues such as low ligand (Tamoxifen) penetration or failure of the ligand to induce recombination, thus explaining the small focal area of epithelial staining. The difference in staining in the two compartments is also likely related to the same effect, as all other controls, such as omission of primary antibody remained negative. Thus, given the overwhelming data from other sources, it is likely the stromal staining reflects continuing Arid1a expression in this specific model system.
Therefore, in conclusion when taken in combination, it is clear that the anti-human ARID1a antibody is cross-reactive with murine tissue and can be used for this purpose.

\section{Data availability}

F1000Research: Dataset 1. Whole slide images from antibody validation of HPA005456 for immunohistochemistry - Version 2, 10.5256/f1000research.5514.d41579 ${ }^{10}$

\section{Author contributions}

WH wrote and conceived the idea behind the article, IG performed the Western blots and mouse experiments and requested validation of ARID1A in murine tissue, JM performed all immunohistochemical staining.

\section{Competing interests}

No competing interests were disclosed.

\section{Grant information}

WH and JM are funded by Cancer Research UK, IG is funded by an MRC Clinical Research Training Fellowship, grant number G1001957.

The funders had no role in study design, data collection and analysis, decision to publish, or preparation of the manuscript.

\section{Acknowledgements}

The authors would like to acknowledge the University of Cambridge, Cancer Research UK and Hutchison Whampoa Ltd. Dr. Peri Tate, Wellcome Trust Sanger Institute, Prof Chambon, IGBMC and Prof Huntsman, British Columbia Cancer Agency for their kind gifts of materials and the staff at the Histopathology/ISH core facility at the Cancer Research UK Cambridge Institute for their assistance in preparing materials for this publication.
1. Streppel MM, Lata S, DelaBastide M, et al.: Next-generation sequencing of endoscopic biopsies identifies ARID1A as a tumor-suppressor gene in Barrett's esophagus. Oncogene. 2014; 33(3): 347-357. PubMed Abstract | Publisher Full Text | Free Full Text

2. Wiegand $\mathrm{KC}$, Hennessy $\mathrm{BT}$, Leung $\mathrm{S}$, et al:: A functional proteogenomic analysis of endometrioid and clear cell carcinomas using reverse phase protein array and mutation analysis: protein expression is histotype-specific and loss of ARID1A/BAF250a is associated with AKT phosphorylation. BMC Cancer. 2014; 14: 120 .

PubMed Abstract | Publisher Full Text | Free Full Text

3. Wiegand KC, Shah SP, Al-Agha OM, et al:: ARID1A mutations in endometriosisassociated ovarian carcinomas. N Engl J Med. 2010; 363(16): 1532-1543. PubMed Abstract | Publisher Full Text | Free Full Text

4. Dulak AM, Stojanov $P$, Peng $S$, et al.: Exome and whole-genome sequencing of esophageal adenocarcinoma identifies recurrent driver events and mutational complexity. Nat Genet. 2013; 45(5): 478-486. PubMed Abstract | Publisher Full Text | Free Full Text

5. Nilsson $\mathrm{P}$, Paavilainen $\mathrm{L}$, Larsson $\mathrm{K}$, et al:: Towards a human proteome atlas: high-throughput generation of mono-specific antibodies for tissue profiling.
Proteomics. 2005; 5(17): 4327-4337.

PubMed Abstract | Publisher Full Text

6. Human Protein Atlas.

Reference Source

7. Wang K, Kan J, Yuen ST, et al:: Exome sequencing identifies frequent mutation of ARID1A in molecular subtypes of gastric cancer. Nat Genet. 2011; 43(12): 1219-1223.

PubMed Abstract | Publisher Full Text

8. Yamamoto S, Tsuda H, Takano M, et al.: Loss of ARID1A protein expression occurs as an early event in ovarian clear-cell carcinoma development and frequently coexists with PIK3CA mutations. Mod Pathol. 2012; 25(4): 615-624.

PubMed Abstract | Publisher Full Text

9. Anglesio MS, Wiegand KC, Melnyk N, et al:: Type-specific cell line models for type-specific ovarian cancer research. PLoS One. 2013; 8(9): e72162. PubMed Abstract | Publisher Full Text | Free Full Text

10. Howat WJ, Miller JL, Gounaris I: Whole slide images from antibody validation of HPA005456 for immunohistochemistry - Version 2. F1000Research. 2014. Data Source 
ID: 10008

Version: 0(current)

Type: IHC staining

Created by: BondPowerUser

Protocol: BABDABR

Creation time: 17/12/2013 11:28

b

\section{Bond-max and Bond-x}

Facility: $<$ not defined $>$

Staining status: Single

\begin{tabular}{|c|c|c|c|}
\hline Step Reagent & & \multicolumn{2}{|c|}{ Supplier: Leica Microsystems } \\
\hline \multicolumn{4}{|c|}{$1 *$ Peroxide Block } \\
\hline Step type: Reagent & Incubation time: $5 \mathrm{~min} 0 \mathrm{~s}$ & Temperature: Ambient & Dispense type: Selected vol. \\
\hline Step Reagent & & \multicolumn{2}{|c|}{ Supplier: Leica Microsystems } \\
\hline \multicolumn{4}{|c|}{$2 *$ Bond Wash Solution } \\
\hline Step type: Wash & Incubation time: $0 \mathrm{~s}$ & Temperature: Ambient & Dispense type: Selected vol. \\
\hline Step Reagent & & \multicolumn{2}{|c|}{ Supplier: Leica Microsystems } \\
\hline \multicolumn{4}{|c|}{$3 *$ Bond Wash Solution } \\
\hline Step type: Wash & Incubation time: $0 \mathrm{~s}$ & Temperature: Ambient & Dispense type: Open \\
\hline Step Reagent & & \multicolumn{2}{|c|}{ Supplier: Leica Microsystems } \\
\hline \multicolumn{4}{|c|}{$4 *$ Bond Wash Solution } \\
\hline Step type: Wash & Incubation time: $0 \mathrm{~s}$ & Temperature: Ambient & Dispense type: Selected vol. \\
\hline Step Reagent & & \multicolumn{2}{|c|}{ Supplier: Vector Laboratories } \\
\hline \multicolumn{4}{|c|}{5 Avidin Block } \\
\hline Step type: Reagent & Incubation time: $10 \mathrm{~min} 0 \mathrm{~s}$ & Temperature: Ambient & Dispense type: Selected vol. \\
\hline Step Reagent & & \multicolumn{2}{|c|}{ Supplier: Leica Microsystems } \\
\hline \multicolumn{4}{|c|}{$6 *$ Bond Wash Solution } \\
\hline Step type: Wash & Incubation time: $0 \mathrm{~s}$ & Temperature: Ambient & Dispense type: Selected vol. \\
\hline Step Reagent & & \multicolumn{2}{|c|}{ Supplier: Leica Microsystems } \\
\hline \multicolumn{4}{|c|}{$7 *$ Bond Wash Solution } \\
\hline Step type: Wash & Incubation time: $0 \mathrm{~s}$ & Temperature: Ambient & Dispense type: Selected vol. \\
\hline Step Reagent & & \multicolumn{2}{|c|}{ Supplier: Leica Microsystems } \\
\hline \multicolumn{2}{|c|}{$8 *$ Bond Wash Solution } & \multirow[b]{2}{*}{ Temperature: Ambient } & \\
\hline Step type: Wash & Incubation time: $0 \mathrm{~s}$ & & Dispense type: Selected vol. \\
\hline$/ 201416: 10$ & & & $1 / 5$ \\
\hline
\end{tabular}


Peica

Protocol: BABDABR

b

Bond-max and Bond-x
Full name: $\mathrm{B} A \mathrm{AB} \mathrm{DABe}$ Rabbit

ID: 10008

Version: 0(current)

Type: IHC staining

Created by: BondPowerUser

Creation time: 17/12/2013 11:28

Facility: $<$ not defined $>$

Staining status: Single

\begin{tabular}{|c|c|c|c|}
\hline Step Reagent & & \multicolumn{2}{|c|}{ Supplier: Vector Laboratories } \\
\hline \multicolumn{4}{|c|}{9 Biotin Block } \\
\hline Step type: Reagent & Incubation time: $10 \mathrm{~min} 0 \mathrm{~s}$ & Temperature: Ambient & Dispense type: Selected vol. \\
\hline Step Reagent & & \multicolumn{2}{|c|}{ Supplier: Leica Microsystems } \\
\hline \multicolumn{4}{|c|}{$10 *$ Bond Wash Solution } \\
\hline Step type: Wash & Incubation time: $0 \mathrm{~s}$ & Temperature: Ambient & Dispense type: Selected vol. \\
\hline Step Reagent & & \multicolumn{2}{|c|}{ Supplier: Leica Microsystems } \\
\hline \multicolumn{4}{|c|}{$11 *$ Bond Wash Solution } \\
\hline Step type: Wash & Incubation time: $0 \mathrm{~s}$ & Temperature: Ambient & Dispense type: Selected vol. \\
\hline Step Reagent & & \multicolumn{2}{|c|}{ Supplier: Leica Microsystems } \\
\hline \multicolumn{4}{|c|}{$12 *$ Bond Wash Solution } \\
\hline Step type: Wash & Incubation time: $0 \mathrm{~s}$ & Temperature: Ambient & Dispense type: Selected vol. \\
\hline Step Reagent & & \multicolumn{2}{|c|}{ Supplier: Not applicable } \\
\hline \multicolumn{4}{|l|}{13 Primary } \\
\hline Step type: Reagent & Incubation time: $15 \mathrm{~min} 0 \mathrm{~s}$ & Temperature: Ambient & Dispense type: Selected vol. \\
\hline Step Reagent & & \multicolumn{2}{|c|}{ Supplier: Leica Microsystems } \\
\hline \multicolumn{2}{|c|}{$14 *$ Bond Wash Solution } & & \\
\hline Step type: Wash & Incubation time: $0 \mathrm{~s}$ & Temperature: Ambient & Dispense type: Selected vol. \\
\hline Step Reagent & & \multicolumn{2}{|c|}{ Supplier: Leica Microsystems } \\
\hline \multicolumn{2}{|c|}{$15 *$ Bond Wash Solution } & & \\
\hline Step type: Wash & Incubation time: $0 \mathrm{~s}$ & Temperature: Ambient & Dispense type: Selected vol. \\
\hline Step Reagent & & \multicolumn{2}{|c|}{ Supplier: Leica Microsystems } \\
\hline \multicolumn{2}{|c|}{$16 *$ Bond Wash Solution } & \multirow[b]{2}{*}{ Temperature: Ambient } & \\
\hline Step type: Wash & Incubation time: $0 \mathrm{~s}$ & & Dispense type: Selected vol. \\
\hline$/ 201416: 10$ & & \multicolumn{2}{|r|}{$2 / 5$} \\
\hline
\end{tabular}


Leica

MICROSYSTEMS

Protocol: BABDABR

b

Bond-max and Bond-x
Full name: $\mathrm{B} A \mathrm{AB}$ DABe Rabbit

ID: 10008

Version: 0(current)

Type: IHC staining

Created by: BondPowerUser

Creation time: 17/12/2013 11:28

Facility: <not defined $>$

Staining status: Single

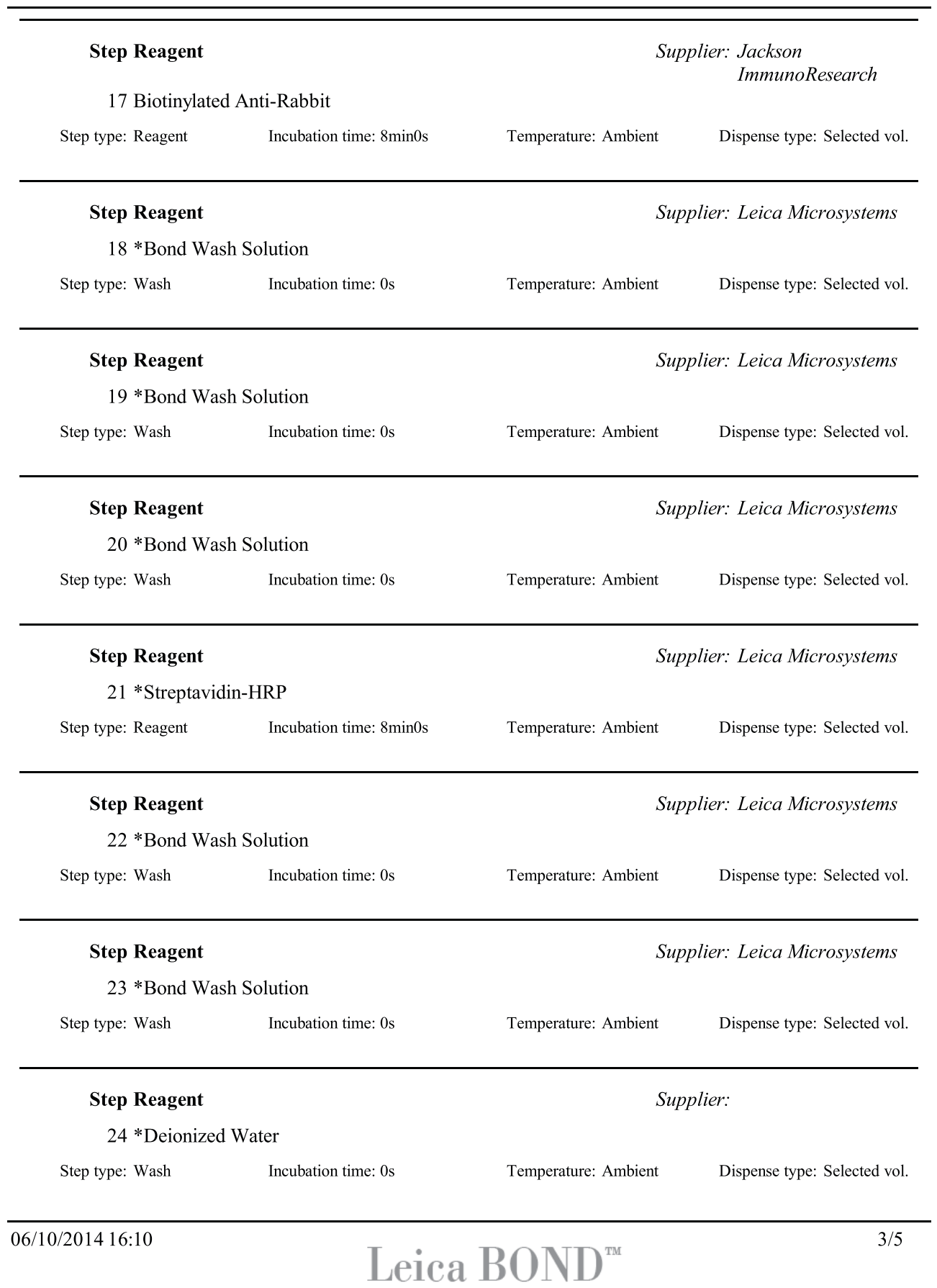


Leicat

Protocol: BABDABR

b

Bond-max and Bond-x
Full name: $B$ AB DABe Rabbit

ID: 10008

Version: 0(current)

Type: IHC staining

Created by: BondPowerUser

Creation time: 17/12/2013 11:28

Facility: $<$ not defined $>$

Staining status: Single

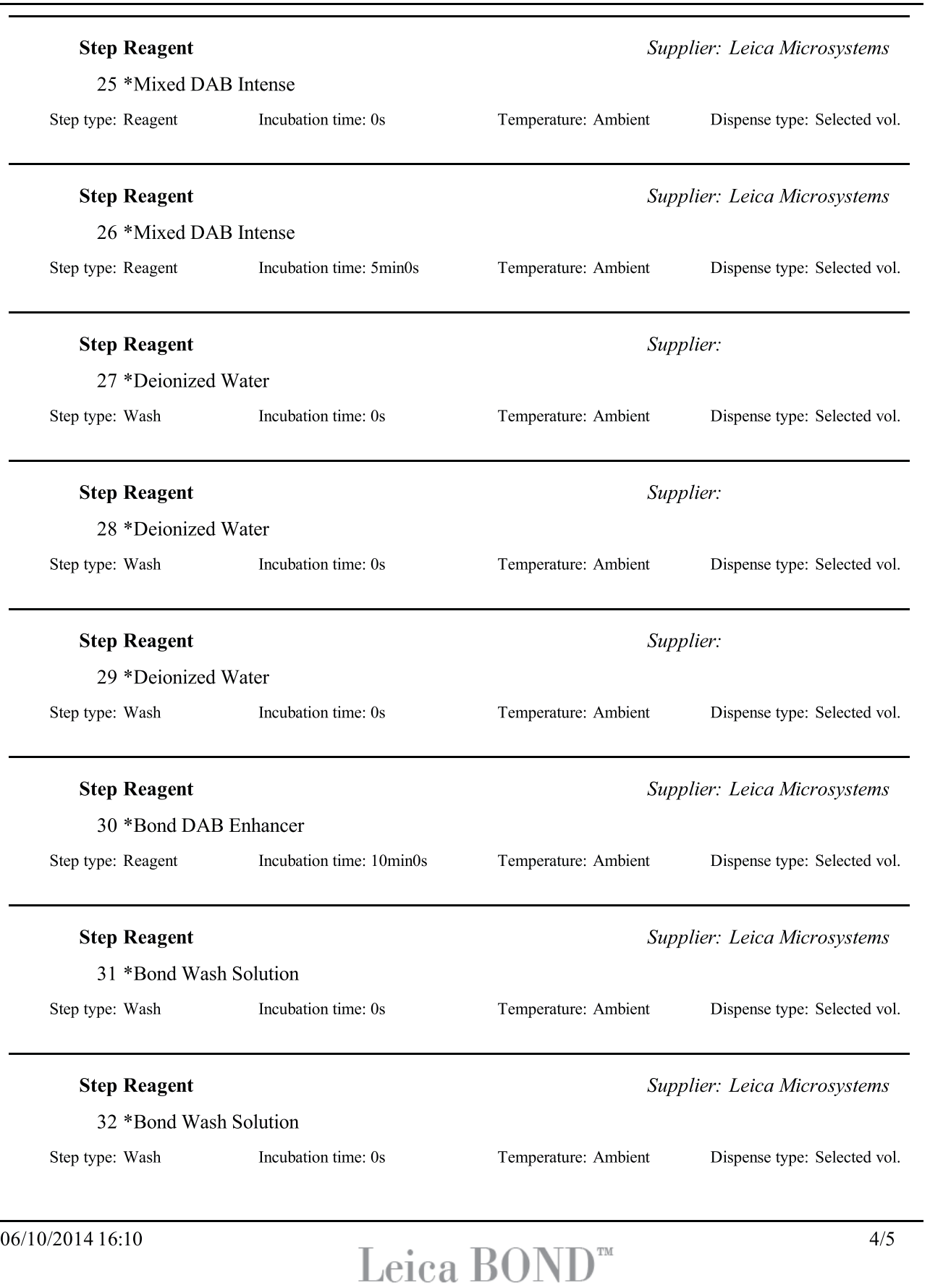


Peicar

Protocol: BABDABR b

\section{Bond-max and Bond-x}

Full name: $B$ AB DABe Rabbit

ID: 10008

Version: 0(current)

Type: IHC staining

Created by: BondPowerUser

Creation time: 17/12/2013 11:28

Facility: <not defined $>$

Staining status: Single

Supplier: Leica Microsystems

Step Reagent

$33 *$ Bond Wash Solution

Step type: Wash

Incubation time: 0

Temperature: Ambient

Dispense type: Selected vol.

Supplier: Leica Microsystems

Step Reagent

$34 *$ Hematoxylin

Step type: Reagent

Incubation time: $5 \mathrm{~min} 0 \mathrm{~s}$

Temperature: Ambient

Dispense type: Selected vol.

Supplier:

Step Reagent

$35 *$ Deionized Water

Step type: Wash

Incubation time: $0 \mathrm{~s}$

Temperature: Ambient

Dispense type: Selected vol.

Step Reagent

$36 *$ Bond Wash Solution

Step type: Wash

Incubation time: 0 s

Temperature: Ambient

Dispense type: Selected vol.

Step Reagent

$37 *$ Deionized Water

Step type: Wash

Incubation time: 0

Temperature: Ambient

Dispense type: Selected vol. 


\section{Open Peer Review}

\section{Current Peer Review Status:}

\section{Version 2}

Reviewer Report 12 January 2015

https://doi.org/10.5256/f1000research.6423.r7236

(C) 2015 McQuaid S. This is an open access peer review report distributed under the terms of the Creative Commons Attribution License, which permits unrestricted use, distribution, and reproduction in any medium, provided the original work is properly cited.

\section{Stephen McQuaid}

Center for Cancer Research and Cell Biology, Queen's University Belfast, Belfast, UK

All concerns have been addressed.

Competing Interests: No competing interests were disclosed.

I confirm that I have read this submission and believe that I have an appropriate level of expertise to confirm that it is of an acceptable scientific standard.

Reviewer Report 09 January 2015

https://doi.org/10.5256/f1000research.6423.r7235

(c) 2015 Chalmers A. This is an open access peer review report distributed under the terms of the Creative Commons Attribution License, which permits unrestricted use, distribution, and reproduction in any medium, provided the original work is properly cited.

\section{Andrew D. Chalmers}

Department of Biology and Biochemistry, University of Bath, Bath, UK

The authors have addressed my comments/concerns satisfactorily and I am happy to approve the manuscript.

Competing Interests: No competing interests were disclosed.

I confirm that I have read this submission and believe that I have an appropriate level of expertise to confirm that it is of an acceptable scientific standard. 


\section{Version 1}

Reviewer Report 02 December 2014

\section{https://doi.org/10.5256/f1000research.5886.r6848}

(C) 2014 McQuaid S. This is an open access peer review report distributed under the terms of the Creative Commons Attribution License, which permits unrestricted use, distribution, and reproduction in any medium, provided the original work is properly cited.

\section{Stephen McQuaid}

Center for Cancer Research and Cell Biology, Queen's University Belfast, Belfast, UK

This article, by Howatt et al. validates an antibody to ARID1A in murine FFPE samples, is a good example of the correct validations procedures that must be met when validating an antibody for use in tissue sections. Issues are relatively minor:

1. What was the rationale for a starting concentration of $1 \mu \mathrm{g} / \mathrm{ml}$ for initial validations?

2. There is a focal region of the KO epithelium which clearly appears to be positive. The authors would need to explain this.

3. Can the authors please add more discussion of the nature of the staining of the stromal cells. Do they consider this to be non-specific? Is such staining of stroma present in human tissue sections?

4. Control slides, omitting primary antibody, were carried out during the cell line phase of the experiments. Were such slides run on the murine tissue sections and can the results be included in the data. I note that the stromal staining was still present at selected concentration of $0.5 \mu \mathrm{g} / \mathrm{ml}$ (dataset $\mathrm{f}$ )

Competing Interests: No competing interests were disclosed.

\section{I confirm that I have read this submission and believe that I have an appropriate level of expertise to confirm that it is of an acceptable scientific standard, however I have significant reservations, as outlined above.}

Author Response 31 Dec 2014

Will Howat, University of Cambridge, Li Ka Shing Centre, Cambridge, UK

Dear Dr McQuaid,

Thank you for your comments which we agree with and have taken on board. Specifically: All of the validations conducted at the Histopathology/ISH facility start with a dilution of 1:100 from the manufacturers provided stock concentration and we perform 3 retrieval methods; Sodium Citrate pH6, Tris EDTA pH9 \& Proteinase K. We titrate as appropriate following establishment of the optimal retrieval method. The 
manufacturers original stock concentration was $100 \mathrm{ug} / \mathrm{ml}$, hence the $1 \mathrm{ug} / \mathrm{ml}$ starting concentration. They have subsequently changed their stock concentration to $200 \mathrm{ug} / \mathrm{ml}$.

We believe that the knockout model recombining a floxed Arid1a with CRE-ERT2 is not $100 \%$ complete as in some cells recombination will not be induced due to issues such as low ligand (tamoxifen) penetration or failure of the ligand to induce recombination. Thus explaining the area of focal staining in the epithelium. Similarly, although we have not investigated this further, we believe that the same problem underlies the stromal staining and is likely due to penetrance of the tamoxifen after being delivered intraperitoneally. Thus, given the wealth of data and the no primary antibody controls, now included in Fig 3, we feel that the stromal staining is not nonspecific. Stromal staining does indeed occur in human tissue.

All of the above have now been included in the conclusion section of the article.

Kind Regards,

Will Howat

Competing Interests: No competing interests were disclosed.

Reviewer Report 21 November 2014

https://doi.org/10.5256/f1000research.5886.r6651

(C) 2014 Chalmers A. This is an open access peer review report distributed under the terms of the Creative Commons Attribution License, which permits unrestricted use, distribution, and reproduction in any medium, provided the original work is properly cited.

\section{Andrew D. Chalmers}

Department of Biology and Biochemistry, University of Bath, Bath, UK

The manuscript by Will Howat and colleagues validates an anti-ARID1A antibody and provides a good example of an antibody validation paper. In particular the use of negative cell lines and knockout mouse tissue demonstrate the extent of specificity of the antibody. The data is mostly well presented and clearly explained in the text.

The manuscript would be suitable for indexing if some, mostly minor, issues can be addressed.

1. I think the title should mention "antibody" to make clear it's an antibody that is being validated.

2. The authors say there is $95 \%$ sequence homology between human and mouse, it would be interesting to see how conserved the sequence the antibody was raised against is.

3. The Materials and Methods give a good overview of the reagents and methods used for the 
IHC, but there is little information about the western blotting. The reagents and methods used should be added.

4. It would be good to cite the source of the cells used and the mouse tissue.

5. I was not clear if the lack of staining in RMG-II cells was expected or an unexpected but useful result? This should be explained.

6. Figure 1 legend. Should read "represents the loading control"

7. In figure $4 \mathrm{~B}$ the $\mathrm{KO}$ epithelium is clearly negative, except one region in the top left which looks positive, I wondered what the authors felt about this?

8. It is interesting that the stromal staining appears to be non-specific, I wonder if the authors ever did a no primary control? Does the stroma still stain? Also it would be worth mentioning this staining in the conclusions.

9. Author contributions. Should it read "conceived the idea behind the article" or similar wording?

Competing Interests: No competing interests were disclosed.

\section{I confirm that I have read this submission and believe that I have an appropriate level of expertise to confirm that it is of an acceptable scientific standard, however I have significant reservations, as outlined above.}

Author Response 31 Dec 2014

Will Howat, University of Cambridge, Li Ka Shing Centre, Cambridge, UK

Dear Dr Chalmers,

Many thanks for your comments which we agree with and have taken on board. Specifically: We have modified the title to read "Application of anti-ARID1a antibody..."

We have BLAST searched the protein sequence and it confirms 95\% homology for the sequence used for immunisations. This has been added to the methods.

We accept that the methods detailing the Western blotting are more limited than the IHC methods, as is the case of the methods detailing the production of the knockout mouse model. However, we feel that the article was designed as an example of antibody validation for immunohistochemistry and that while western blotting provides important additional data, it is not the focus of the article. We thus feel that there is sufficient information in the details behind the western blotting to repeat the experiment, without clouding the article with the full methods.

The sources of the cells and mouse tissue have now been cited. 
The lack of staining of RMG-II cells was consistent with the literature (Anglesio et al.) and this information has been added to the results section.

The figure legend has been modified.

We believe that the focal staining is a result of incomplete recombination floxed Arid1a allele and Cre/ERT2. The resulting knockout is almost never $100 \%$ complete as in some cells recombination will not be induced due to issues such as low ligand (tamoxifen) penetration or failure of the ligand to induce recombination. Similarly, we believe that the staining in the stromal compartment is specific but represents a failure of delivery of Tamoxifen or of recombination. The data from no primary antibody (NPA) control which are all completely clean, now included in Fig 3, helps to demonstrate this. We have included these points in the conclusion.

The author contributions have been modified.

Kind Regards,

Will Howat

Competing Interests: No competing interests were disclosed.

\section{Comments on this article}

\section{Version 2}

Reader Comment 12 Jan 2015

Jan Voskuil, Everest Biotech Ltd, Oxfordshire, UK

Well done!

Competing Interests: No competing interests were disclosed. 
The benefits of publishing with F1000Research:

- Your article is published within days, with no editorial bias

- You can publish traditional articles, null/negative results, case reports, data notes and more

- The peer review process is transparent and collaborative

- Your article is indexed in PubMed after passing peer review

- Dedicated customer support at every stage

For pre-submission enquiries, contact research@f1000.com 